Dept. of Food Control,

Faculty of Veterinary Medicine, Zagazig University

\title{
PREVALENCE OF AEROBIC SPORE FORMING BACILLI WITH SPECIAL REFERENCE TO BACILLUS CEREUS IN YOGHURT AND RICE BUDDING
}

(With 4 Tables)

By

\author{
E.I. $A W A D$
}

(Received at 4/9/2008)

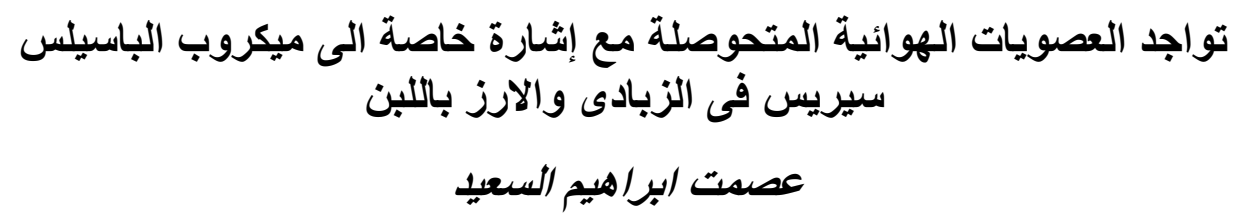

أجريت الدر اسة علي ثلاثون عينة من كل من الزبادي والأرز باللابن المجمعة من أماكن مختلفة

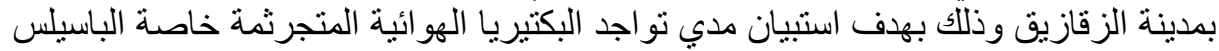

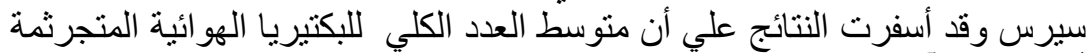

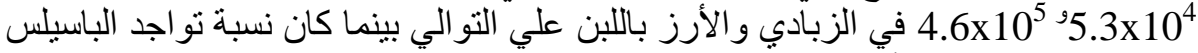

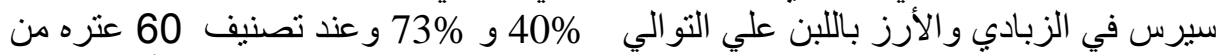

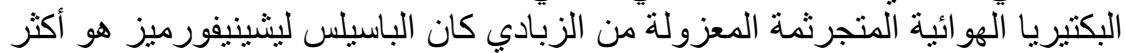

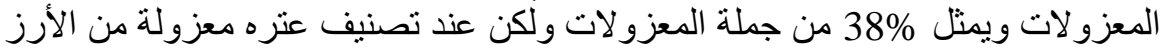
باللبن تبين أن الباسيلس سيرس هو الأكثر تو اجدا ولئل ويمثل

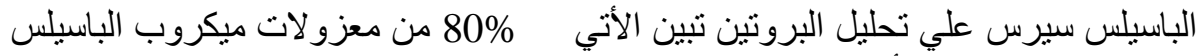

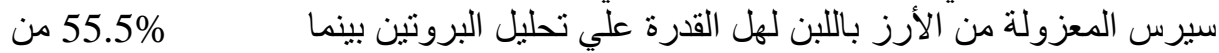

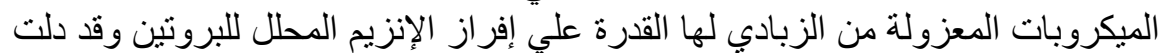

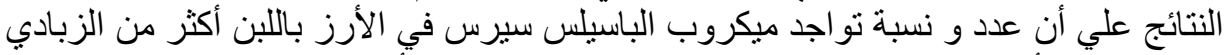

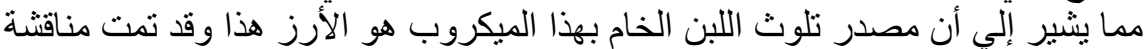
النتائج لبيان أهميتها الصحية و الاقتصادية.

\section{SUMMARY}

A total of 60 samples including (30 plain yoghurt and 30 rice budding) were collected from dairy shops, supermarkets and groceries in Zagazig city, Egypt and analyzed for enumeration of their Aerobic spore-formers and Bacillus cereus counts. The proteolytic activity of isolated Bacillus cereus was also investigated. The results obtained showed that mean counts of Aerobic spore-formers in the examined yoghurt and rice 
budding samples respectively were $5.3 \times 10^{4}$ and $4.6 \times 10^{5}$, while Bacillus cereus could be isolated from $12(40 \%)$ and $22(73 \%)$ with mean counts of $1.3 \times 10^{3}$ and $1.6 \times 10^{5}$ of the examined samples, respectively. Out of 60 Bacillus spp. isolated from examined yoghurt samples, Bacillus licheniformis was predominating and comprising 23(38\%) while 9 (15\%) isolates proved to be Bacillus cereus and on the other hand Bacillus cereus was predominating other Bacillus spp. isolated from rice budding samples 25(42\%). 20 (80\%) out of 25 Bacillus cereus obtained from rice budding samples possessed proteolytic activity compared to $5(55.5 \%)$ isolates from yoghurt samples. Results were discussed in the context of present microbiological specifications and the need for its implementation by regulatory agencies to ward off possible health hazards arising from these microorganisms.

Key words: B. cereus, yoghurt, rice budding

\section{INTRODUCTION}

Fermented milk is the most popular fermented dairy products produced in Egypt and world wide. The value of fermented milk in human nutrition is based not only on the nutritive value of milk from which it is made and increased digestibility due to changes of milk constituents during fermentation period but also on the beneficial effect of intestinal micro flora, prophylactic and healing effect (buttress, 1997; Hussein and Kebary, 1999 and Zedan et al., 2001).

Fermented milk has a positive effect on human defense system and cardiovascular diseases (Piaia, 2001) and high intake of fermented products was associated with decrease risk of ulcer (Elmstahl et al., 1998).

Yoghurt is highly nutritious food of useful therapeutic value as it prevents the intestinal putrefaction resulting from anaerobic decomposition, prevents the gastrointestinal disorder, prevents coronary heart disease, reduces the risk of colon cancer, exerts a hypocholesterolaemic effect and produces antibiotics as acidophilin, lactocidin, nicin and lactoline that inhibit the growth of many pathogens (Robinson, 1991).

The rice budding and custard are the most popular varieties of Egyptian dairy desserts used not only in villages but also in cities .Rice budding ingredients are milk sugar, rice and other additives such as vanillin, raisins and shaved coconut to enhance its nutritive value and improve its flavor (Ray, 1996). 
Heat resistant Psychrotrophs predominating Bacillus spp. can be introduced into milk supplies from water, udder, teat surfaces, soil or from milk stone deposits on farm bulk tanks, pumps, pipelines, gaskets and processing equipment and these organisms produce proteinases which result in the development of objectionable flavor and quality defects in dairy products (Meer et al., 1991).

Bacillus cereus had been reviewed in food poisoning cases linked with milk and dairy products and there are two clinical forms of Bacillus cereus food poisoning, one is called diarrheal form that resemble to Clostridium perfringens food poisoning while the second form is called emetic syndrome food poisoning (Mossel, 1982). Infection of human by Bacillus cereus may be complicated by bronchopneumonia and otitis (Eley, 1996).

The unique combination of both thermoduric and Psychrotrophic properties of Bacillus cereus represents recurring problems for dairy industries such as spoilage of pasteurized milk (sweet curdling) and cream (bitty cream) under the effect of proteolytic and lipolytic actions (Griffiths, 1990).

In recognition of the public health and economic significance of Aerobic spore-formers especially Bacillus cereus, therefore the present study was undertaken to investigate its presence in milk and dairy products.

\section{MATERIALS and METHODS}

A total of 60 samples including (30 plain yoghurt and 30 rice budding) were collected from dairy shops, supermarkets and groceries in Zagazig city, Egypt.

\section{Preparation of samples (A.P.H.A., 1992):}

The sample containers were mixed thoroughly using sterile spatula before examination. Eleven gram of the prepared samples were added to $99 \mathrm{ml}$ of peptone water in a sterile bottles and thoroughly mixed to make a dilution of $1 / 10$, from which decimal serial dilutions were prepared.

\section{Methodology (A.P.H.A., 1992):}

1- Enumeration and identification of Aerobic spore-formers and Bacillus cereus.

Dextrose tryptone agar medium (Oxoid, 1999) and Bacillus cereus medium (Biolife, 1993) were used for enumeration of Aerobic 
spore-formers and Bacillus cereus respectively. Isolated colonies were purified and identified according to Cowan and Steel (1974)

\section{2-Determination of proteolytic activity of isolated Bacillus cereus} (Harrigan and McCance, 1976)

Overnight cultures were spot inoculated onto pre-poured plates of standard plate count agar with $10 \%$ added skim milk. The inoculated plates were incubated at $25 \hat{\mathrm{C}}$ for 48 hours and subsequently flooded with $10 \% \mathrm{~W} / \mathrm{V}$ acetic acid, appearance of clear zone around the colonies after one minute exposure were regarded as positive.

\section{RESULTS}

Table 1: Aerobic spore-formers count/gram of examined samples $(\mathrm{n}=30)$.

\begin{tabular}{|c|c|c|c|c|c|c|}
\hline \multirow{2}{*}{ Samples } & \multicolumn{2}{|c|}{$\begin{array}{c}\text { Positive } \\
\text { samples }\end{array}$} & \multirow{2}{*}{ Minimum } & Maximum & Mean & IS.E.M \\
\cline { 2 - 3 } & No & $\%$ & & & \\
\hline Yoghurt & 26 & 87.0 & $3.0 \times 10^{3}$ & $4.2 \times 10^{6}$ & $5.3 \times 10^{4}$ & $2.1 \times 10^{4}$ \\
\hline Rice budding & 28 & 93.0 & $2.8 \times 10^{4}$ & $2.6 \times 10^{7}$ & $4.6 \times 10^{5}$ & $2.5 \times 10^{5}$ \\
\hline
\end{tabular}

*-ve samples $>100$

Table 2: Bacillus cereus count/gram of examined samples $(\mathrm{n}=30)$

\begin{tabular}{|c|c|c|c|c|c|c|}
\hline \multirow{2}{*}{ Samples } & \multicolumn{2}{|c|}{$\begin{array}{c}\text { Positive } \\
\text { samples }\end{array}$} & \multirow{2}{*}{ Minimum } & Maximum & Mean & 土S.E.M \\
\cline { 2 - 7 } & No & $\%$ & & & & \\
\hline Yoghurt & 12 & 40.0 & $1.0 \times 10^{2}$ & $3.2 \times 10^{4}$ & $1.3 \times 10^{3}$ & $0.4 \times 10^{3}$ \\
\hline Rice budding & 22 & 73.0 & $1.8 \times 10^{4}$ & $2.2 \times 10^{6}$ & $1.6 \times 10^{5}$ & $0.5 \times 10^{5}$ \\
\hline
\end{tabular}

$*$-ve samples $>100$

Table 3: Frequency distribution of Bacillus spp. isolated from examined samples.

\begin{tabular}{|c|c|c|c|c|}
\hline \multirow{2}{*}{ Isolates } & \multicolumn{2}{|c|}{ Yoghurt } & \multicolumn{2}{|c|}{ Rice budding } \\
\hline & $\mathrm{NO}$ & $\%$ & $\mathrm{NO}$ & $\%$ \\
\hline Bacillus cereus & 13 & 22.0 & 25 & 42.0 \\
\hline Bacillus licheniformis & 23 & 38.0 & 16 & 27.0 \\
\hline Bacillus coagulans & 12 & 20.0 & 14 & 23.0 \\
\hline Bacillus mycoides & 12 & 20.0 & 5 & 8.0 \\
\hline Total & 60 & 100.0 & 60 & 100.0 \\
\hline
\end{tabular}


Table 4: Proteolytic activity of isolated Bacillus cereus

\begin{tabular}{|c|c|c|c|}
\hline Samples & No of isolates & Positive isolates & $\%$ \\
\hline Rice budding & 25 & 20 & 80.0 \\
\hline Yoghurt & 13 & 5 & 38.5 \\
\hline
\end{tabular}

\section{DISCUSSION}

The results given in Table 1 showed that out of the examined 30 yoghurt samples $26(87 \%)$ were positive for Aerobic spore-formers. The high level of Aerobic spore-formers contamination was $4.2 \times 10^{6}$, the low level was $3.0 \times 10^{3}$ and the mean value was $5.3 \times 10^{4}$ while Aerobic sporeformers could be isolated from 28 (93\%) of the examined rice budding samples and the count ranged from $2.8 \times 10^{4}$ to $2.6 \times 10^{7}$ with a mean value of $4.6 \times 10^{5}$. Nearly similar finding was reported by Rangasamy et al. (1993) and Said and Fahmy (1991)

Information derived from the results reported in Table 2 revealed that Bacillus cereus could be isolated from $12(40 \%)$ and $22(73 \%)$ with a mean counts of $1.3 \times 10^{3}$ and $1.6 \times 10^{5}$ of the examined yoghurt and rice budding samples respectively. These findings were in agreement with those reported by Sallam et al. (1991), Rangasamy et al. (1993), Notermans et al. (1997) and Warke et al. (2000) while Giffel et al., (1996) recorded lower values.

The results presented in Table 2 declared that the incidence and count of Bacillus cereus in examined rice budding samples are higher than yoghurt. The Bacillus cereus spores are often found in cereals especially rice and some spores are surviving cooking and subsequently germinated into Bacilli which, under warm storage condition in cooked food grow and produce toxins (Hobbs and Roberts, 1993). Bacillus cereus can be introduced into milk via sources other than raw milk and the equipment is probably an important source of contamination. Bacillus cereus spores were predominantly transmitted from feed, via feces to farm bulk tank milk (Vissers et al., 2007). In fermented milk and cheese vegetative Bacillus cereus are rapidly eliminated during production process (Schoder et al., 2007)

Out of 60 Bacillus spp. isolated from examined yoghurt samples, Bacillus licheniformis was predominating and comprising 23(38\%) while $13(22.0 \%)$ isolates proved to be Bacillus cereus and on the other hand Bacillus cereus was predominating other Bacillus spp. isolated 
from rice budding samples 25(42\%) (Table, 3). These findings were in agreement with those reported by Meer et al. (1993) and Zhou et al. (2008). Bacillus cereus is a common cause of two types of food-borne illnesses, the diarrheal type is characterized by abdominal cramps and diarrhea 8-16 hours following ingestion while emetic type is characterized by vomiting 1-5 hours after ingestion of incriminated food (Schoder et al., 2007 and Svensson et al., 2007). Other spore-forming organisms such as Bacillus licheniformis have also been reported as agents of food poisoning with similar characteristics to those of Bacillus cereus (Hobbs and Roberts, 1993).

The results given in Table 4 showed that out of 25 Bacillus cereus obtained from rice budding samples, 20 (80\%) were possessed proteolytic activity while only 5 (38.5\%) out of 13 Bacillus cereus isolates isolated from yoghurt samples. Nearly similar finding was reported by Awad (1996). The thermoduric bacteria do not influence on the keeping quality of either raw and heat treated milk except those produced spores. The later are responsible for spoilage of pasteurized (sweet curdling) and occasionally raw milk which has been kept at low temperature as cream (bitty cream) under the effect of proteolytic and lipolytic action (Schoder et al., 2007)

\section{REFERENCES}

A.P.H.A "American public health Association" (1992): Standard method for the examination of dairy products. $16^{\text {th }}$ Ed., NewYork.

Awad, E.I. (1996): Study of proteolytic psychrotrophic microflora in raw buffaloe's milk. M.V.Sc., Faculty of Vet. Medicine, Zagazig Univ., Egypt.

Biolife, (1993): Quality Assurance Laboratory. Milano, Italy.

Buttress, J. (1997): Nutritional properties of fermented milk products. Int. J Dairy Technol., 50: 21.

Cowan, S.T. and Steel, K.J. (1974): Manual for the identification of medical bacteria. $2^{\text {nd }}$, Cambridge Univ., Press, England.

Eley, A.R. (1996): Microbiological food poisoning. $2^{\text {nd }}$ Ed., Chapman and Hall, London.

Elmstahl, S.; Svensson, U. and Berglund, G. (1998): Fermented milk products are associated ulcer disease. Results from across sectional populattion study. Eur. J. Clin. Nutr., 52(9): 668-674. 
Giffel, M.C.; Beumer,R.R.; Bonestroo, M.H. and Rombouts, F.M. (1996): Incidence and characterization of Bacillus cereus in two dairy processing plants. Netherlands Milk and Dairy Journal 50(4): 479-492.

Griffiths, M.W. (1990): Bacillus cereus in liquid milk and other milk products. Bulletin of the International Dairy Fedration 275: 3639.

Harrigan, W.F. and McCane, M.E. (1976): Laboratory methods in food and dairy microbiology. Academic Press London, New York, San Francisco.

Hobbs, B.C. and Roberts, D. (1993): Food poisoning and Food Hygiene 6th Edition. Singular publishing, Group INC. San Diego, California.

Hussein, S.A. and Kebary, K.M.K. (1990): Improving viability of Bifidobacteria by microenterapment and their effect in stirred yoghurt. Acta Alimentaria, 28: 113.

Meer, R.R.; Baker, J.; Bodyfelt, F.W. and Griffiths, M.W. (1991):

Psychotrophic Bacillus spp. In fluid milk products: A review J. of Food Protection 54 (12): 969-979.

Meer, R.R.; Wodburn, M.J. and Bodyfelt, F.W. (1993): Identification and characterization of heat resistant Psychotrophic bacteria in Oregon Grade A raw milk. Dairy, Food and Enviromental sanitation 13 (11): 631-637.

Mossel, D.A.A. (1982): Microbioogy of foods. 3rd Edition. The Univ. of Utrecht, the Netherlands.

Notermans, S.; Dufrenne, J.; Teunis, P.; Beumer, R.; Giffel, M. and Weem, P.P. (1997): A risk assessment study of Bacillus cereus present in pasteurized milk. Food Microbiology 14 (2): 143151.

Oxoid, (1990): The oxoid manual. 6th Edition, Unipath Ltd., United Kingdom.

Piaia, M. (2001): Fermented milk and successful aging. Danone World Newsletter No. 22: 1-14.

Rangasamy, P.N.; Iyer, M. and Roginski, H. (1993): Isolation and characterization of Bacillus cereus in milk and dairy products manufactured in Victoria. Australian J. of Dairy Tech. 48 (2): 93-95.

Ray, B. (1996): Fundamental Food Microbiology CRC Press, Inc., Tokyo, New York. 
Robinson, R.K. (1991): Therapeutic properties of fermented milks. Elsevier applied scientific publishers, London.

Said, M.R. and Fahmy, M. (1991): A survey of incidence of Staphylococcus aureus, Esherichia coli and Bacillus cereus in some types of Egyptian cheeses in Assiut city. Assiut J. of Agricultural Science 22 (2): 239-246.

Sallam, S.S.; Hafez, N.M.; El-Kholy, A.M. and Amer, I.H. (1991): Incidence of Bacillus cereus in milk and some dairy products in Egypt. J. Egypt. Vet. Med. Ass. 51 (1\&2): 153-159.

Schoder, D.; Zangerl, P.; Manafi, M.; Wagner, M.; Lindner, G. and Foissy, H. (2007): Bacillus cereus - A foodborne pathogen of different risk potential for the dairy industry. Wiener Tierarztliche Monatsschrift 94 (1\&2): 25-33.

Svensson, B.; Monthan, A.; Guinebretiere, M. and Nguyen, C. (2007): Toxin production potential and the detection of toxin genes among strains of Bacillus cereus group isolated along the dairy production chain. International Dairy J.17 (10): 1201-1208.

Vissers, M.M.M.; Giffel, M.C.; Driehuis, F.; De Jong, P. and Lankveld, J.M.G. (2007): Minimizing the level of Bacillus cereus spores in farm tank milk. J. Dairy Sci.90: 3286-3293.

Warke, R.; Kamat, A.; Kamat, M. and Thomas, P. (2000): Incidence of pathogenic Psychrotrophs in ice creams sold in some retail outlets in Mumbai, India. Food Control 11: 77-83.

Zedan, M.A.; Zedan, A.N.; Kebary, K.M.K. and Mahmoud, S.F. (2001): Effects of fortification of cows milk with acetylated whey protein concentrates on the quality of set yoghut. Egyptian J. Dairy Sci., 29: 285-297.

Zhou, G.; Liu, H.; He, J.; Yuan, Y. and Yuan, Z. (2008): The occurrence of Bacillus cereus, Bacillus thuringiensis and Bacillus mycoides in Chinese pasteurized full fat milk. International J. of food Microbiol.121(2): 195-200. 